\section{俩 Heighten Science \\ P U B L I C I T I O N S Corporation ISSN 2575-0135}

\title{
Non-chemical control of Armillaria mellea infection of Prunus persica
}

\author{
Jim Downer* and Ben Faber \\ University of California, Cooperative Extension, 669 County Square Drive Suite 100 Ventura CA, \\ 93003, USA
}

\begin{abstract}
*Address for Correspondence: Jim Downer, University of California, Cooperative Extension, 669 County Square Drive Suite 100 Ventura CA, 93003, USA, Tel: 805825 9081; Email: ajdowner@ucanr.edu

Submitted: 17 June 2019

Approved: 03 July 2019

Published: 04 July 2019

Copyright: @ 2019 Downer J, et al. This is an open access article distributed under the Creative Commons Attribution License, which permits unrestricted use, distribution, and reproduction in any medium, provided the original work is properly cited
\end{abstract}

Keywords: Armillaria mellea; Yardwaste; Trichoderma; Planting hole; Peach; Prunus persica

Check for updates

\section{Abstract}

Peaches, Prunus persica were planted as grafted saplings in an avocado orchard previously infested with Armillaria mellea (Vahl) P.Kumm. Trees were planted in large or small holes with or without fresh yardwaste chips added as an amendment and with or without a Trichoderma biocontrol product sprayed into the hole. Trees were monitored for six years -- growth and mortality was tabulated. Six years later $40 \%$ of the trees had died from the disease. Trees planted in a large hole were more likely to survive than in a smaller hole $(P=0.07)$ and trees in large holes with fresh organic matter added were the most likely to survive $(P=0.04)$. Trichoderma sprays in the planting hole did not increase survival rates. While growth was initially retarded by adding fresh yardwaste to the hole, in later years none of the treatments affected growth rates.

\section{Introduction}

Armillaria mellea is the pathogen that causes root rot of many forest and ornamental and agronomic trees [1,2]. The pathogen occurs in landscapes and urban soils as well as a natural pathogen in forests and on lands converted to farming. While symptoms can appear suddenly, it is generally considered a slowly developing pathogen that takes years to kill a tree. When infected trees begin to die and are removed from orchards the fungus rapidly colonizes the remaining roots and resides in soil as potential inoculum for trees planted later (3).

Armillaria is difficult to control. Fungicides are not effective and even the most effective fumigants such as methyl bromide may not completely eradicate Armillaria from soils (3). Sterol demethylation inhibiting fungicides can be effective in slowing and preventing Armillaria infections in grape and stone fruit crops [4]. Fungicides if used frequently are subject to breakdown in effectiveness through pathogen resistance to the treatment [5].

Adding uncomposted organic matter to soil provides the carbon and energy necessary to build microbial populations in soil, some of which are antagonistic to Armillaria. Mulches of bark and fresh woody debris of Scots pine increased soil microbial activity and organisms (fungi) eleven years after treatment. In this study both Trichoderma koingii and fresh wood and bark mulches applied to soil increased $T$. verde [6]. Tree wood products such as yardwste or tree trimmings wastes are effective substrate for culture of many different fungi including Trichoderma spp. Downer et al. [7], found that Armillaria mellea only survived a maximum of 11 days in fresh yardwaste static piles and that recovery of viable Armillaria was negatively associated with increases in Trichoderma in the wood chips.

Trichoderma spp. have long been understood to play a role in control of Armillaria mellea, especially after fumigation of soil [8-10]. Some effectiveness has been shown 
with Trichoderma applied in concert with other non-chemical methods [10]. Pellegrini and others [12] found that Armillaria could be controlled by applying barks preinoculated with Trichoderma atroviride.

Managing Armillaria root rot diseases is likely best achieved with integrated approaches as all control methods have limitations [13]. Four years after treatment, Schnable and others [14], did not find that Trichoderma controlled Armillaria in a peach orchard but did show growth increases of Trichoderma treated peaches. Baumgartner [15], found that root collar excavations gave control of active Armillaria infections and that excavated grape vines had receding mycelial fans. Root collar excavation did not eradicate the pathogen from infected vines.

There are limitations to most methods of control. Fumigants and fungicides typically do not reach all of the infested roots [15], nor are they truly eradicative, so the pathogen can grow back when they degrade or their effects wear off. Trichoderma is a rapid soil colonizer during post fumigation conditions, or perhaps after soil disturbance, but rapidly converts itself to spores once soil perturbations have passed. Four years after treatment, Schnable and others [14] did not find that Trichoderma controlled Armillaria in a peach orchard but did show slight growth increases of Trichoderma treated peaches.

Planting hole size along with added amendments have been recommended in commercial orchard situations in publications and the practice has been followed by growers world-wide [16-18,24]. The various reasons given for making large planting holes have been to disrupt any limiting layers and to create a more conducive environment for root growth. In the case of replanted deciduous orchards, it has been found to be beneficial to actually replace the native soil in the hole with pathogen free soil [19]. However, in many cases, research has shown that holes much larger than the planting ball and using organic amendments can cause problems for many tree species [20,21]. Improper mixing of the organic amendment can cause anaerobic conditions that can occur with settling of the amendment. Crown rot can occur with the buried stems [21].

In our study we investigate two potential cultural controls (hole size and yardwaste amending) and one biological treatment (Trichoderma application) on their ability to help peach trees survive Armillaria infested soil.

\section{Materials and Methods}

Peaches (Prunus persica 'Galaxy' doughnut cultivar on 'Nemagaurd' rootstock) were planted in January of 2004 in Carpinteria, Ca, in an avocado orchard that was infested with Armillaria mellea. Peaches were planted as bare root grafted seedlings with initial caliper of $2.5 \mathrm{~cm}$ at the graft union. Trees were subjected to combinations of three possible treatments: 1 . an increased planting hole volume; 2 . presence of organic amendment; 3. presence of Trichoderma inoculant.

Trees were planted in either a standard hole of $0.13 \mathrm{~m}^{3}$ or a large hole $2 \mathrm{~m}^{3}$ in volume excavated with a mini excavator to $1 \mathrm{~m}$ depth. In large holes, backfill was replaced and the tree set at the same depth as in small holes.

Large holes were not amended or amended with fresh yardwaste chips with a C: $\mathrm{N}$ ratio of 200:1 particle size of 3-6cm consisting of chipped branches of mixed tree species (Pine, oak, Eucalyptus, Ficus) and other yard trimmings. Yard waste was applied at $0.33 \mathrm{~m}^{3}$ per hole and thoroughly mixed with backfill soil.

Promote Plus (J.H. Biotech, Ventura, CA), a combination of Trichoderma harzianum and Trichoderma konigii $\left(2 \times 10^{7} \mathrm{CFU} / \mathrm{ml}\right.$ and $3 \times 10^{7} \mathrm{CFU} / \mathrm{ml}$ respectively) was applied per manufacturer's instructions with a backpack sprayer to holes with and without organic amendment. Spray volume of $250 \mathrm{ml}$ was applied to each hole. 
Trees were irrigated with drip irrigation, pruned and cultivated according to standard farming practices. Trees were pruned one time for structural correction in August of 2004. In the fall of 2004, Nitrogen (ammonium sulfate) was applied to all trees in the study. One Kg per tree applied on the soil surface and dissolved with rainfall. Fertilizer was not subsequently applied after this.

Trees stem diameters were measured in $\mathrm{cm} 0.5 \mathrm{~m}$ above the soil surface on the main stem with a Haglof tree caliper (Forestry Supply, Jackson, MS).

The experimental design was a nested factorial, randomized complete block design with nine replications. Mortality data were analyzed with Minitab 17 (Minitab LLC, State College, PA) using binary logistic regressions. Growth data were analyzed with one way ANOVA.

\section{Results}

All of the peaches established and grew in the first year. In the first measurement, we observed growth reduction in trees amended with yardwaste (Figure 1). Hole size did not influence growth rate. All trees in the study were fertilized with Nitrogen and growth differences disappeared in future measurements. Other than above, hole size, Trichoderma application or organic amendment did not significantly increase or decrease peach tree calipers throughout the study.

Tree mortality (Image 1) was tabulated each year (data only shown for last tabulation). We found a trend that trees survived longer ( $\mathrm{P}=0.07)$ in larger holes than in a standard small planting hole. Two thirds of the trees died in the small holes, whereas, two thirds survived in the big holes. The addition of yardwaste to large holes increased survival significantly $(\mathrm{P}=0.04)$ over large holes not so amended. Holes treated with Trichoderma did not influence tree survival in our study (Table 1).

\section{Discussion and Conclusion}

Long-term study of Armillaria disease development is difficult because the pathogen

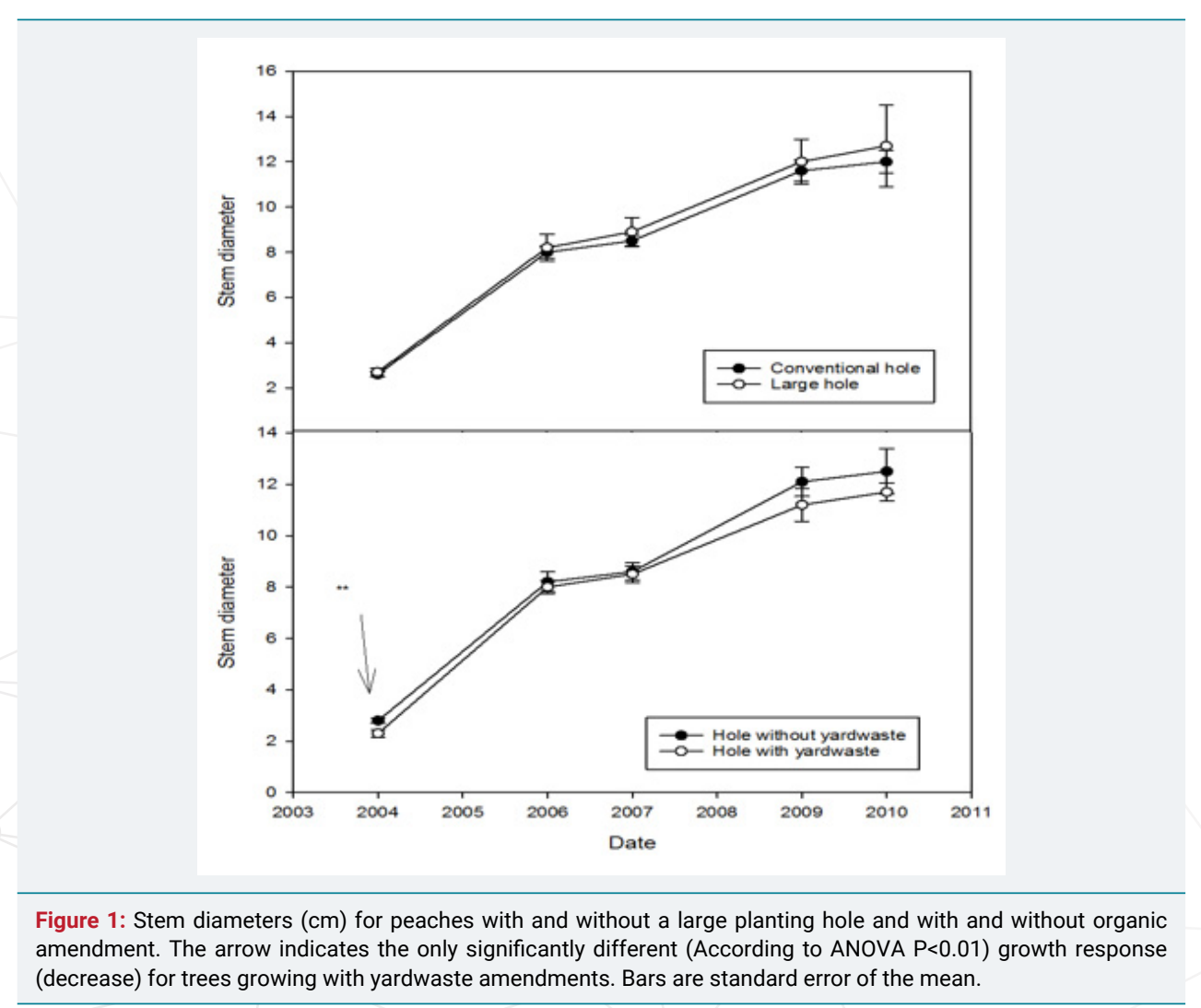




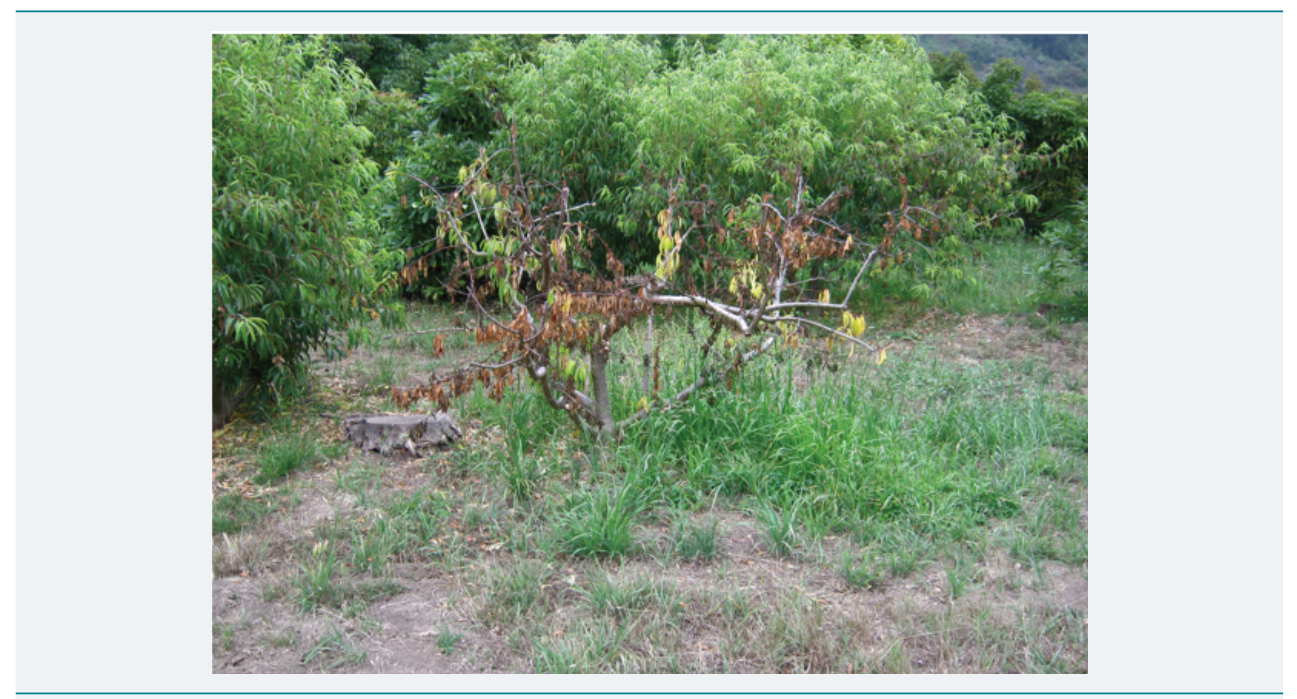

Image 1: Dead peach tree in conventional hole, fully girdled by Armillaria mellea. Healthy peaches in the background. Note old stump (left of dyeing peach) of Avocado that had previously died of Armillaria serving as inoculum source.

\begin{tabular}{|c|c|c|c|c|c|c|}
\hline & \multicolumn{6}{|c|}{ Treatment factor } \\
\hline & \multicolumn{2}{|c|}{ Hole Size } & \multicolumn{2}{|c|}{ Yardwaste } & \multicolumn{2}{|c|}{ Trichoderma } \\
\hline & Large hole & Small hole & + & - & + & - \\
\hline Live $^{1}$ & 24 & 3 & 14 & 13 & 13 & 14 \\
\hline Dead & 12 & 6 & 4 & 14 & 5 & 13 \\
\hline$\%$ survival $^{2}$ & $66 a$ & $33 b$ & $78 a$ & $48 b$ & 72 & 50 \\
\hline $\begin{array}{l}\text { Chi-Square } \\
\text { and } P \text { value }\end{array}$ & \multicolumn{2}{|c|}{$3.28 ; P=0.070$} & \multicolumn{2}{|c|}{$4.11 ; P=0.043$} & \multicolumn{2}{|c|}{$1.91 ; P=0.167$} \\
\hline \multicolumn{7}{|c|}{$\begin{array}{l}{ }^{1} \text { Numbers in rows are live and dead tree counts for each category from } 2010 \text {. } \\
{ }^{2} \text { Percent survival is the percent surviving infection in each column. Letters signify significant differences ( } P<10 \% \text { for } \\
\text { Hole size and } P<5 \% \text { for Yardwaste) according to binary logistic regression } \\
{ }^{3} \text { Chi-square and } P \text { values for the regression model respectively for each treatment variable (column) }\end{array}$} \\
\hline
\end{tabular}

may not be evenly distributed in a field, conditions may vary in the area under study and edaphic factors can vary or change during the course of study. We were fortunate in this study to have a field with an even distribution of dead trees, their stumps left in the ground to serve as inoculum for our newly planted peach trees. We planted as many trees as we had room for and assigned treatments to obtain nine replications. Given more or less optimal site conditions to favor disease in peach, disease development is often not even or regular. The study was run for 6 years before the grower decided to remove the trees. Looking at the final count of surviving trees and their treatments, we are able to make some conclusions and suggestions for further study.

The logic behind making a large two cubic meter hole is to disturb the Armillaria inoculum with the backhoe tractor bucket. Any visible root pieces were extracted and thrown aside. Soil disturbance perturbs the soil microbial food web, creating a pulse of biological activity [22]. This could account for increased attack on Armillaria surviving in buried root pieces, thus depreciating the inoculum. The peach replants have two cubic meters of soil to explore with relatively small amounts of inoculum present and thus an increased trend toward survival. This cautious finding should be restudied with more replication.

Adding organic amendments to planting holes is often a source of tree establishment problems. In agricultural settings, amendments are rarely incorporated because of the issues of overseeing proper establishment over large areas planted with numerous trees. Adding an organic amendment in most settings is not suggested, especially not fresh, uncomposted materials that could cause root damage from excessive heat and gases produced in a closed environment like a planting hole. The lag in growth noted 
in the early stages of the tree planting also should be underscored. The growth lag might have been reduced by the addition of more frequent, small amounts of nitrogen fertilizer.

Adding fresh yardwaste to the large holes provides the substrate for increased microbial activity particularly Trichoderma spp. that survive on wood substrates. Adding wood likely increased the native populations of Trichoderma already present on site, (this was not measured). Fresh yardwaste is a carbon source for the growth of many bacterial and fungal antagonists, singly or collectively having impact on any surviving inoculum. It is not surprising therefore that more peaches survived in large holes amended with fresh yardwaste than in any other treatments.

Adding Trichoderma to the planting pits was not associated with tree survival. This is likely because adequate Trichoderma populations were already resident in the yardwaste or on site. Our study suggests that deep ripping a field infested with Armillaria, adding fresh organic matter, especially woody high C:N ratio tree wastes can promote survival of peach in Armillaria infested soils. Additional studies of this kind with larger disturbed areas and more replication are necessary to verify these preliminary findings.

\section{References}

1. Raabe RD. Host list of the root rot fungus. Armillaria mellea. Hilgardia. 1962; 33: 25-88. Ref.: http://bit.ly/2XnEwns

2. Shaw CG, Kile GA. Armillaria root disease. Forest Service United States Department of Agriculture. Agriculture Handbook. 1991; 691.

3. Raabe R. Testing plants for resistance to oak root fungus. California Agriculture. 1966; 20: 12-13. Ref.: http://bit.ly/2xBvvrD

4. Adaskaveg JE, Förster H, Wade L, Thompson DF, Connell JH. Efficacy of sodium tetrahthiocarbonate and propiconazole in managing armillaria root rot of almond on peach rootstock. Plant Dis. 1999; 83: 240-246. Ref.: http://bit.ly/307ZrYh

5. Ishii $\mathrm{H}$. Impact of fungicide resistance in plant pathogens on crop disease control and agricultural environment. Jpn Agric Res. 2006; 40: 205-211 Ref.: http://bit.ly/2XHBBW2

6. Malecka M, Kwasna $H$, Szewzyk W. Fungal communities in barren forest soil after amendment with different wood substrates and their possible effects on trees, pathogens, insects and nematodes. $J$ of Plant Protection Res. 2015; 55: 301-311. Ref.: http://bit.ly/2NuYxUz

7. Downer AJ, Crohn D, Faber B, Daugovish O, Becker JO, et al. Survival of Plant pathogens in static piles of ground green waste. Phytopathology. 2008; 98: 547-554. Ref.: http://bit.ly/2Xmj1hM

8. Munnecke DE, Kolbezen MJ, Wilbur WD. Effect of methyl bromide or carbon disulfide on Armillaria and Trichoderma growing on agar medium and relation to survival of Armillaria in soil following fumigation. Phytopathology. 1973; 63: 1352-1357. Ref.: http://bit.ly/2Jp9p0x

9. Ohr HD, Munnecke DEBricker JL. The interaction of Armillaria mellea and Trichoderma spp. As modified by methyl bromide. Phytopathology. 1973; 63: 695-973. Ref.: http://bit.ly/306utQq

10. Munnecke DE, Kolbezen MJ, Wilbur WD, Ohr HD. Interactions involved in controlling Armillaria mellea. Plant Dis. 1981; 65: 384-389. Ref.: http://bit.ly/2xozQhp

11. Percival GC, Smiley ET, Fox RTV. Root collar excavation with Trichoderma inoculations as a potential management strategy for honey fungus (Armillaria mellea). Arboricultural J. 2011; 33: 267-280. Ref.: http://bit.ly/2J6P1CB

12. Pellegrini A, Prodorutti D, Pertot I. Uses of bark mulch pre-inoculated with Trichoderma atroviride to control Armillaria root rot. Crop Protection. 2014; 64: 104-109. Ref.: http://bit.ly/2KTKS7p

13. Fox RTV. Managing Armillaria root rot. Food Agric. Environ. 2003; 95: 95-100. Ref.: http://bit.ly/2Jj9VNZ

14. Schnabel G, Rollins AP, Henderson GW. Field evaluation of Trichoderma spp. for control of Armillaria root rot of peach. Plant Health Progress. 2011. Ref.: http://bit.ly/2Yq8aF2

15. Baumgartner K. Root collar excavation for post infection control of Armillaria root disease of grapevine. Plant Dis. 2004; 88: 1235-1240. Ref.: http://bit.ly/2XHPTG8 
16. Donadio LC. Present status of Brazillian avocado industry. Proceed. First World Avocado Congress in S. African Growers' Ass. Yearbook. 1987. 10: 82-85. Ref.: http://bit.ly/2YtfWhd

17. Texeira CE, Bleinroth EW, de Castro JV, De Martin ZJ, Tango JS, et al. Abacate: cultura, materialprima, processamento e aspectos economicos. $2^{\text {nd }}$ Ed. ITAL-Campinas. 1992; 250.

18. Choo KK. Longan production in Asia. FAO RAP Pub: 2000/20. Rome, Italy. 2000; 126.

19. McKenry MV. The replant problem and its management. Catalina Publishing Co. Fresno, CA. 1999; 126.

20. Whitcomb CE. Amendments and tree establishment. J Arbormiculture. 1979; 5: 217-219.

21. Harris RW, Cklark JR, Matheny NP. Arboriculture. Prentice Hall. Upper Saddle River, New Jersey. 2004; 578.

22. Ferris $\mathrm{H}$, Matute MM. Structural and functional succession in the nematode fauna of a soil food web. Applied Soil Ecology. 2003; 23: 93-110. Ref.: http://bit.ly/2Yv40Am

23. Aguín 0 , Mansilla JP, Sainz MJ. In vitro selection of an effective fungicide against Armillaria mellea and control of white root rot of grapevine in the field. Pest Management Sci. 2006; 62: 223-228. Ref.: http://bit.ly/2NsS50f

24. Anonymous. El cultivo del Aguacate. $2^{\text {nd }}$. Federacion Nacional de Cafeterios de Colombia. Programa de Desaroollo y Diversificaion de Zonas Cageteras. 1982; 23.

25. Raabe RD. Some previously unreported hosts of Armillaria mellea in California, III. Plant Dis Rep. 1979; 63: 494-495. Ref.: http://bit.ly/30b1gDN 